\title{
KVINNER SOM OFRE
}

Av førsteamanuensis, dr. Philos. Tove Stang Dahl, Oslo

\section{Lovbrytere og ofre}

Både kriminologien og kriminalpolitikken har langt på vei holdt ofrene for kriminalitet utenfor sitt interessefelt. Ofrene finnes ikke i kriminalstatistikken, statistikken gir bare indikatorer på risikosituasjoner i enkelte og svært grove sammenheng, f. eks. m. h.t. åsted og tidspunkt for kriminalitet, og. noen enkle kjennetegn ved lovbryterne.

Ofrene finnes nesten heller ikke i de kriminologiske lærebøkene. Engang iblant kommer de til syne, men oftest som appendiks til gjerningsmennene som har den egentlige kriminologiske interesse. Selve offerlæren, viktimologien, er bare undergitt en prinsipiell behandling i én av de mest brukte nordiske lærebøkene, og også i denne svært kortfattet.

Ofrene har heller ikke fått noen systematisk plass i kriminalpolitikken. De har mest stått fram gjennom konservative og generelt formulerte lovog-orden krav. Offerordninger har oppstått på annet vis - utenfor kriminalpolitikken. I første omgang som privatøkonomiske kompensasjonsordninger gjennom erstatning og forsikring, senere også som tvungne forsikringsordninger som f. eks. bilforsikring. Man kan også se deler av folketrygdsystemet og helse- og sosialvesenet som problemmottakere og reparatører av kriminalitetsskader, men ordningene er ikke etablert med offerskader for øyet, og fungerer derfor lite tilfredsstillende fra offersynspunkt.

I 1976 ble det i Norge vedtatt en ordning med offentlig kompensasjon til visse ofre for vold. Jeg sier med vilje »til visse«, for silingen av verdige of re er streng, selv om vi i Norden - som Patrik Törnudd sa i går - visstnok er langt framme internasjonalt med denne type tiltak. Jeg skal komme nærmere tilbake til ordningen senere fordi den illustrerer noen almene trekk ved problemet kvinner som of re.

Kriminologien har således vært preget av en sterk lovbryterorientering. Over tid har denne fagorienteringen bidratt til å skape større forståelse for tradisjonelle lovbrytere, særlig vinningsforbrytere, men også sedelighetsog voldsforbrytere. Fra en sterk individorientering med vekt på patologiske og iboende egenskaper hos lovbryteren og sosiale kjennetegn i hans nærmeste miljø som ărsak til kriminalitet, har kriminologien utviklet seg mot et helhetssyn, ivor kriminalitet er resultat av samspill over flere nivåer: gjerningsmannen selv og hans miljø, i ytterligere samspill med lovgivning, politi- og rettspraksis - for derigjennom å se gjerningsmannen som produkt av samfunn og samfunnsmessig plassering. Denne helhetlige forståelse har hatt som naturlig resultat at kriminalitet langt på vei ses som en forlengelse 
av det normale liv - ikke vesensforskjellig, bare gradsforskjellig fra dette. Lovbryterorienteringen har skiftet fra vekt på patologi og avvik til en naturlig konklusjon om at mange gjerningsmenn mer er of re for systemer enn aktører bak uakseptable handlinger, d. v. s. at de tradisjonelle lovbrytere er ressurssvake grupper som heller trenger støtte enn straff.

Utviklingen i synet på kriminalitet som utslag av økonomisk og annen fattigdom har ført den nordiske etterkrigskriminologi - og kanskje i særlig grad den norske med Christie i spissen - inn i en sterk linje om ikke-intervensjon når det gjelder strafferettslige tiltak. I Goldschmidts terminologi, som han har skapt ut fra det grønlandske eksempel, bør det heller være tale om å utvise størst mulig aktiv toleranse overfor gjerningsmannen enn straff og isolasjon. ${ }^{1}$ )

Denne kriminalsosiologiske retning har nedlagt store fortjenester i å fremme en mer virkelighetsnær og human kriminalpolitikk. Den har også bidratt til en berettiget avdramatisering av kriminalpolitikken og øket forståelsen for gjerningsmennenes offersituasjon i samfunnet.

På den annen side innebærer det ikke å intervenere overfor en gjerningsmann samtidig å unnlate å gi offeret støtte - det være seg som nødhjelp mot fortsatte angrep eller moralsk og psykisk ved å stemple atferden. Fra offersynspunkt blir slike hensyn særlig viktige i de situasjoner hvor offeret har gått til det skritt å anmelde forholdet eller på annen måte gitt uttrykk for ønske om påtale, og hensynene forsterkes dersom forholdet mellom offer og gjerningsmann er slik at de p. g. a. sin sosiale situasjon fortsatt har kontakt med hverandre.

Det siste vil ofte være tilfelle med kvinnelige ofre.

Generelt kan man si at ikke-intervensjon og aktiv toleranse vil ha få betenkeligheter ved seg dersom gjerningsmennene er ekstra svake eller ofrene relativt sett sterke. Sterke ofre kan langt på vei forsvare seg mot angrep og reparere skader. Forsikringsordninger garderer ressursrike individer og selskaper mot tyveri, innbrudd og skadeverk. Interne kontrollordninger på offersiden må balanseres i forhold til offerets ønskemål: f. eks. når supermarkedene organiserer sitt varetilbud gjennom et fristelsestrykk som nødvendigvis må virke både salgs- og tyverifremmende. Ofre har i slike situasjoner ikke sarlig sterke krav på støtte gjennom statlig intervensjon.

Mer uklart blir det når ofrene er tilnærmet likestilte med gjerningsmennene og f. eks. like svake som dem. Det blir stadig mer erkjent i kriminologien at dette vanligvis er forholdet når det er tale om tradisjonell vinnings-, sedelighets- og voldskriminalitet. Dette perspektiv er det særlig viktimologien som forskningsgren som har bidratt til å trekke fram. Man både stjeler fra og angriper sine egne i langt større grad enn utenforstående. Det er få

1) Goldschmidt 1978 . 
statushopp mellom gjerningsmenn og ofre. Fattige stjeler fra fattige. Svarte dreper svarte i USA. Alkoholiserte hjemløse slåss med andre alkoholiserte hjemløse i Norden. Folk fra høyere statuslag utsettes sjeldnere for hverdagslivets formues- og voldsforbrytelser enn folk fra fattige miljøer, o. s. v. Slik erkjennelse har utkrystallisert seg i teorier om »the precipitated victim " - det påskyndende, medvirkende, deltakende, provoserende offer, som også har del i det kriminelle resultat - ja i visse situasjoner endog større del i det enn gjerningsmannen. Det kan være tilfeldig hvem som blir offer og hvem som blir gjerningsmann, sies det. »Fyllekrangel« nevnes gjerne som et typisk eksempel, »husbråk « som et annet, voldtekt som et tredje.

Det deltakende perspektiv på interaksjonen mellom gjerningsmann og offer kan gi et ekstra forsvar til politikken om ikke-intervensjon ved å unnskylde eller rettferdiggjøre gjerningsmannens handlemåte. Men samtidig kan en slik holdning bidra til å sette svake gruppers liv og helse på spill i situasjoner hvor offeret er enda svakere enn gjerningsmannen, og derfor skulle trenge sæerlig beskyttelse. Voldtektssaker gir etter min mening ofte gode eksempler på dette.

Slik sett blir spørsmålet om ikke-intervensjon og aktiv toleranse vanskeligere når ofrene er systematisk svakere enn gjerningsmennene, og dette er den situasjonen kvinnelige ofre oftest befinner seg i. Bl. a. av denne grunn vil jeg i det følgende innta en offersympatiserende holdning. Det vil også gå fram at jeg vil stille meg kritisk til ikke-intervensjonslinjen, som ikke bare finnes i kriminologisk teori men også i håndhevingspraksis - jeg har allerede nevnt voldtektssaker som eksempel. Dette betyr imidlertid ikke at øket slrafferettslig intervensjon vil være den beste løsning - det finnes også andre måter å intervenere og beskytte offeret på.

Relativt få kvinner er lovbrytere, men mange kvinner er ofre. Kvinner utsettes for alle former for tradisjonell kriminalitet - både vinnings-, sedelighets- og voldsforbrytelser, men ikke på linje med menn og ikke på samme måte som menn, fordi kvinner besitter andre typer ressurser og lever andre typer liv enn menn gjør. Selv om vinningskriminaliteten er den overveldende form for tradisjonell kriminalitet, er kvinner i liten grad i risikosonen, ganske enkelt fordi vinningskriminalitet forutsetter visse ressurser i form av penger eller eiendom, som kvinner sjelden har.

Forholdet er et annet når det gjelder sedelighetskriminalitet naturligvis. Denne kriminalitetsform er i høyeste grad kvinnerelevant ved at det hovedsakelig er kvinner som er målgrupper og ofre for seksualforbrytelser, ganske særlig gjennom voldtekt og voldtektsliknende forbrytelser. På sedelighetens område besitter kvinner attråverdige ressurser som det i vår kultur ikke er uvanlig for menn å gå til angrep på, selv om bare et fåtall av disse overgrep blir anmeldt og enda færre blir pådømt.

Voldtektsforskningen er et felt hvor teorien om det framskyndende og derfor medskyldige offer tidligere sto sterkt, men hvor resultatene og syns- 
måtene er blitt svekket gjennom kvinneforskningen i de senere år. $\left.{ }^{2}\right)$ Likevel har teorien om det aktive voldtektsoffer fortsatt støtte i politi- og domstolspraksis i mange land. At voldtekt er farlig for offeret, er på den annen side veldokumentert gjennom forskning om ofrenes fysiske og særlig deres psykiske skader.

Det kunne vært fristende å bruke resten av tiden på kvinner som voldtektsofre fordi situasjonen er så praktisk og teoriperspektivet så viktig for hva man gjør med problemet. Jeg gir meg likevel ut på det tredje tradisjonelle felt - volden.

\section{Vold mot kvinner: privallivets ufred}

Vold mellom kvinner later til å være et sjeldent fenomen, $\mathrm{i}$ alle fall om man holder tidligere tiders barnedrap og strafferettslige fosterfordrivelse, og nåtidens barnemishandling, utenfor. Man vet for øvrig lite om i hvilken grad mødre mishandler sine barn og enda mindre om hvorvidt døtre i så fall er særlig utsatt ${ }^{3}$ ).

Det er få data om vold mellom kvinner, men det synes som den domineres av de mindre legemskrenkelser mellom kvinner som kjenner hverandre, særlig naboer $\left.{ }^{4}\right)$.

Det er hovedsakelig menn som øver vold mot kvinner, og denne volden later til å være av en ganske omfattende og ofte alvorlig karakter.

Kvinner som voldsofre har vært skjult i dobbelt forstand - både generelt som ofre for kriminalitet, og spesielt som ofre bak dogmet om privatlivets fred. For det er i hjemmet at volden foregår - den volden som gjør kvinner til kriminalitetsofre $\mathrm{i}$ en klasse for seg. Hjemmet som åsted later til å være lukket for offentligheten, og offentligheten later til å lukke seg for innsikt i privatlivets ufred.

Dogmet om privatlivets fred har sterke tradisjoner i jussen og politikken. Ekteskapskontrakten er en avtale mellom tre parter - mannen, kvinnen og staten - hvor staten trer til ved kontraktsinngåelse og -oppløsning, men trer tilbake som interessent mens ekteskapet består. Forholdet overlates

2) I Norden er kvinneperspektivet særlig brakt inn gjennom Lykkjen 1976 og Rasmussen og Kongstad 1980, (under trykking), Weis and Borges 1973, Brownmiller 1975 og Russel 1975 kan nevnes blant internasjonale bidrag i framveksten av denne tradisjon. Amir 1971 er et klassisk arbeid med vektlegging på teorien om det deltakende offer.

3) Vold mot barn var den form for familievold som først ble »oppdaget « og fulgt opp av forskere gjennom kartlegging av »the battered child syndrome « i 1960 årene, jfí. den oppstartende artikkel av Kempe et al. 1962. Etter dette er mange prosjekter satt i gang og mye skrevet om barnemishandling, men kjønnsvariablen er dårlig tatt vare på både når det gjelder lovbryter og offer.

4) Gummedal 1973. 
ektefellene med det resultat at den sterkeste part - mannen - nyter dogmets beskyttelse, også når han utøver utilbørlig styring og makt, derunder vold ${ }^{5}$ ).

Det er ikke bare politi og domstoler som fører en ikke-intervensjonspolitikk overfor voldelige ektemenn. Også hos sosiale myndigheter, helsevesen, privatpraktiserende leger eller jurister og skilsmissemyndigheter, later det til å råde en tilsvarende ideologi. Man vil helst ikke blandes inn, man bør ikke blande seg inn. Det skal mye til for at vold i seg selv er rettslig relevant for hjelp til skilsmisse eller til ny bolig. Mye av denne vegring kan skyldes en til nå manglende kunnskap om problemene, og manglende evne til å gjøre noe med det. Mye kan f. eks. tyde på at både politi, helsepersonell og sosialkontorer føler seg maktesløse når de møter de forslåtte hustruene i konkrete saker $\left.{ }^{6}\right)$.

Siden vi i dag særlig retter lyset på kriminalpolitikken, kan bildet illustreres av hvordan ofre for familievold utelukkes fra den offentlige kompensasjonsordning til voldsofre. I kgl. res. av 11. mars 1976 står det i § 3: »Erstatning etter disse forskrifter ytes ikke til skadevolderens ektefelle som bor sammen med ham eller til annen person som lever i ekteskapsliknende samliv med ham, med mindre særlige grunner gjør det rimelig.« Det er altså mulig å gi erstatning til mishandlete hustruer dersom særlige grunner foreligger. "Sæerlige grunner « er ett av de sterkeste lovgivningstekniske uttrykk som anvendes for å begrense en regel, og når et slikt krav kommer i tillegg til en rimelighetsbetraktning som allerede er stilt som alminnelig: begrensende vilkår for erstatning i § 1, er utelukkelsen av hustruer særdeles grundig. Det meste av hustruvolden ville likevel blitt unntatt gjennom den alminnelige skjønnsvurdering - slik hustruvold stort sett blir unntatt myndighetskontroll med mindre den er ekstrem. Her er vi nemlig tilbake til teoriene om de deltakende ofre, som ikke bare er framherskende i sedelighetssaker mot voksne kvinner, men også i voldssaker. Da spørsmålet om å oppheve det spesielle unntak for ofre for ektefellevold kom opp i Stortingets spørretime, la justisminister Valle nettopp vekt på dette hensyn.

$\left.{ }^{5}\right)$ I forbindelse med det første norske forslag til lov om likestilling mellom kjonnene reiste feministgrupper og kvinneorganisasjoner kritikk mot forslaget fordi privatlivet var unntatt lovens virkeområde. Kritikken ble imøtekommet ved å innlemme privatlivet, men unnta familielivet fra lovens håndheving, et lovteknisk grep som er beskrevet flere steder i rettssosiologien, se Dahl m. fl. 1975.

$\left.{ }^{6}\right)$ Kriscsenter-rapporter fra inn- og utland formidler denne erfaring, likedan intervjuer med myndigheter og profesjonelle og erfaringene er beskrevet spredt rundt i den refererte familievoldslitteratur. Se f. eks. Martin, J. P. ed. 1978, Moore 1979 for engelske og amerikanske forhold. I Norge har forskere ved Krisesentret i Oslo intervjuet personale ved Oslos 6 politistasjoner, ved bydelspolitiet, ved 11 av 21 sosialkontorer og ved legevakten. (Aslaksen og Nisja 1979, upubliserte arbeidsnotater). 
Jeg siterer:

"Bakgrunnen for at skader i familielivet er unntatt er i første rekke at det i slike forhold er særlig vanskelig å vurdere betydningen av skadelidtes opptreden. Det kan f. eks. ha vært et dårlig forhold i familien i lengre tid, eller skadelidte kan ha opptrådt provoserende. Videre kan det være fare for misbruk av ordningen med skadeserstatning når skadevolder og skadelidte tilhører samme familie med felles økonomi. $\ll^{7}$ )

Denne for så vidt lille saken om skadeserstatning til voldsofre er talende for myndighetsholdninger til hustruvolden.

For det første: det skal meget til for å erkjenne at det foreligger alvorlig vold som det bør gjøres noe med. Erstatningsskadeordningen gjelder bare personskader voldt ved straffbar handling. Allerede her vil det ligge en sikkerhet mot at ikke-berettigede kvinner skulle kunne komme til å få erstatning. For, som jeg senere vil ta opp, skal det mye til for at hustruvold blir anmeldt og pådømt. Det foregår en langt sterkere siling av skyldige gjerningsmenn her enn i andre voldssammenhenger. I tillegg kommer erstatningsordningens dobbeltsikring gjennom to omganger skjønn.

For det andre: det er barrierer mot å se familievoldens kjønnsspesifikke karakter. $§ 3$ bruker uttrykket »ektefelle« og »han« - det er tradisjonelt og hensiktsmessig lovspråk. Det er riktig at selve ordningen bør være kjønnsnøytral idet kvinner og menn bør stilles likt ved tildeling av rettigheter når de kommer opp i samme situasjon - selv om det ene kjønn er lite risikoutsatt. Men Valles svar var også helt kjønnsnøytralt, og det er tilslørende. Den kjønnsnøytrale ordbruk om privatvolden strekker seg i mange sammenhenger for langt og er med på å usynliggjøre familievoldens karakter og kjønnsretning. I politiets radiologg, vaktjournaler og arkiver faller hustrumishandling og annen familievold inn under kategorien "husbråk«, en kategori som for klarhetens skyld burde splittes opp, all den stund husbråkutrykningene opptar mye av politiets tid og all den stund en vesentlig del av utrykningene skyldes hustrumishandling både i Norge og i andre land. Den nøytrale ordbruk og de grove kategorier er med på å holde ofrene skjult.

For det tredje: justisministeren uttalte som motargument at det kunne ha vært et dårlig forhold i familien. Ja, der har hun rett. Hustruvold later til å ha en gjentatt, vedvarende og eskalerende karakter og bidrar til en angstfylt og vanskelig hverdag. Men det gjør vel ikke ofrene mindre beskyttelsesverdige?

For det fjerde: hun henviser til en provokasjonsteori som hun ikke er alene om. Denne teori har etter min mening to hovedsvakheter. Den forutsetter tilnærmet likestilte ofre, et forhold som ikke holder i praksis fordi 
kvinnen gjennomgăende er den svake part i ekteskapet. Dessuten legitimerer den volden. Volden er forbudt, men tolereres likevel.

For det femte: hun henviser til farene for misbruk av ordningen ut fra fellesfølelse mellom mann og hustru. Selv i slike sammenhenger som dette, hvor mannen er dømt for straffbar handling mot kona, understrekes altså familieharmonien og samholdet. Jeg gad se de ektepar som fabrikkerer straffbar vold for å oppnå pengeerstatning fra staten. Denne aksiomatiske familieharmoniseringen er en holdning som ikke sjelden møter mishandlede hustruer som henvender seg til myndighetene for å få hjelp.

\section{Krisesentrene}

1970-årene har gitt oss klar kunnskap om at vold mot kvinner - særlig i form av hustruvold - er utbredt. Synliggjøringen har i første rekke skjedd gjennom opprettelse av krisesentre for mishandlede kvinner i en rekke land, men også gjennom en tiltakende forskningsinteresse for spørsmålet særlig i USA og Storbritannia - i siste halvdel av tiåret. Dessuten kan man plukke sammen opplysninger fra tidligere kriminologisk forskning for å kaste ytterligere lys over problemet.

Krisesenteridéen fikk først feste i England. Det startet gjennom et kvinnepolitisk tiltak i London, der det første krisesentret ble åpnet i 1972. I løpet av de neste 5 år oppsto 70 slike krisesentre i forskjellige engelske byer og 16 i Skottland ${ }^{\mathrm{S}}$ ).

I 1976 samlet over 2000 kvinner fra 40 land seg på Brysseltribunalet for »Forbrytelser mot kvinner «. Vold var et sentralt tema på tribunalet og krisesenterbevegelsen fikk gjennom dette en mektig stimulans ${ }^{9}$ ). USA hadde på det tidspunkt også sine sentre, men de var i første rekke opprettet for å ta imot voldtatte kvinner, og i andre land var sentre både for mishandlede og voldtatte pâtenkt $\left.{ }^{10}\right)$. En internasjonal krisesenterbevegelse tok form. I dag finnes det - så langt jeg vet - sentre i England, Skottland, Holland, Frankrike, Tyskland, Sveits, i 30 av USA's 50 stater, Canada, Australia og Japan.

I Norden har vi vært sent ute. Det første overnattingssentret åpnet i Oslo 2. mai 1978. Dette skjedde under inspirasjon av de engelske erfaringene og Brysseltribunalet hvor flere norske feminister hadde deltatt. Krisesentergruppa som ble nedsatt etter Brysselmøtet ble møtt med skepsis og tvil m. h. t. problemets eksistens i Norge og Norden, hvor likestillingspolitikken er

8) Om opprettelsen og erfaringene fra London-sentret, se Pizzey 1974. Om organisasjon, finansiering m. v. av engelske og skotske sentre, se Melville 1978, Renvoize 1979, $29 \mathrm{ff}$, Alfredsson 1979, $145 \mathrm{ff}$. For amerikanske og kanadiske, se Martin 1976.

9) Forhandlingene er utgitt i Russell and Van de Ven ed. 1976.

10) I 1977 fantes det ca. 100 voldtektssentre i USA, Becker and Abel 1977. 
kommet så langt, og behovet måtte dokumenteres ytterligere før gruppa maktet å vinne gehør. Dokumentasjonene skjedde dels gjennom de erfaringer vi hadde innhentet fra rettshjelparbeid fra og til kvinner gjennom organisasjonen Fri rettshjelp for kvinner (senere omdøpt til Juridisk rådgivning for kvinner - JURK) som ble startet i 1974 av studenter og lærere ved Det juridiske fakultet i Oslo. (Jeg skal komme tilbake til dette senere.) Dessuten ble det åpnet en krisetelefon med økonomisk støtte fra et aksjonsforskningsprosjekt i kvinnekriminologisk arbeidsgruppe ved Institutt for kriminologi og strafferett for å dokumentere behovet ${ }^{11}$ ).

Etter at krisesentret nå har vært $\mathrm{i}$ drift ett år, er behovet ytterligere avdekket. Sentret tar imot så mange som det har kapasitet for med sine 8 hybler og en tilstøtende leilighet $\mathrm{i}$ et kommunalt bygg, og iblant er det så overfylt av kvinner og barn at det kan synes på grensen av det forsvarlige. I alle fall er det slik at hver gang sentret omtales i kringkasting eller lokalpresse, kommer nye henvendelser som svar. Samme erfaring har vi fra arbeidet i JURK: en følelse av at behovet er umettelig og at vi må være på vakt mot for mye PR for ikke å bli nødt til å avvise.

I krisesentrets første årsrapport, som omfatter de første 8 måneder, var det 2530 overnattinger, 1660 voksne og 870 barn, d. v. s. 10,5 overnattinger pr. døgn fordelt pá 98 kvinner, pluss barn. $93 \%$ er mishandlet av ektefelle, samboer, tidligere ektefelle og $3 \%$ av sønn. Gjennomsnittlig bor kvinnene i 17 dager på sentret ${ }^{12}$ ). I dag finnes det krisetelefoner i Bergen og Trondheim og sentre er også under planlegging flere steder i Norge.

Finland er for tiden i en aktiv etableringsfase idet tre familievoldssentre (sentrene er altså ikke spesifikke kvinnesentre) ble åpnet i april 1979 og et fjerde er planlagt åpnet i løpet av sommeren. I Danmark har Joan-søstrene til nå fungert som kontaktsenter med samtale- og gruppetilbud til mishandlede kvinner. Men de har ikke egne overnattingsmuligheter og må nøye seg med å henvise kvinnene til pensjonater, noe erfaring viser er en vesentlig svakhet ved tilbudet. I Sverige diskuterer ulike kvinnegrupper om man skal lage et krisesenter, et kvinnehus eller en kombinasjon av begge deler. Lokaler for en av ordningene er skaffet.

Den internasjonale krisesenterbevegelsen er en del av den nye kvinnebevegelsen i samarbeid med deler av de gamle kvinneorganisasjonene. Det er sentre av og for kvinner, et forhold som stadig påkaller offentlig oppmerksomhet i disse likestillingstider. Hvorfor får ikke menn være med å drive? spørres det. Blir ikke også menn mishandlet, men da psykisk? Og er ikke det like alvorlig? Trenger ikke også menn krisesentre? o. s. v. Poenget er bare at det nettopp er sentrenes spesielle kvinnekarakterer som gjør at

11) Aksjonsforskningsprosjektet er beskrevet i Fodstad og Steen 1977.

12) Årsrapport for »Krisesentret for mishandla og voldtatte kvinner « v/ Aslaksen og Krogstad 1978. 
de fanger inn nye kvinnegrupper som søker støtte, i tillegg til de kvinner som allerede har hatt myndighetskontakter for sitt problem. Det er således to grupper kvinner som fanges inn: det er de som har prøvet de fleste hjelpeordninger - noen av kvinnene ved sentret i Oslo henvises fra politi, sosialkontor o.s. v., og det er en ganske stor gruppe kvinner som ikke har delt sine problemer med noen før, men rømt til sin mor eller andre slektninger når volden er blitt for stri. Den samme erfaring har vi i JURK - at mange kvinner oppsøker oss som første instans og sier eksplisitt at de våger å henvende seg fordi vi er kvinner og fordi vi har uttalt at vårt formål spesielt er å hjelpe kvinner.

$\mathrm{Og}$ her er vi ved et kjernepunkt. Når mishandlede kvinner kommer til krisesentret, behøver de ikke forklare hvorfor de kommer. Alle vet det. Ofrene slipper å legge fram sin sak før de er sterke nok eller har lyst til å ta den opp. De får i første omgang et fysisk tilfluktssted for seg og eventuelle barn, inntil, eller om de har lyst til å gå videre for å gjøre noe mer med saken, eller dra hjem igjen.

M. h.t. ressursene som finnes for å ta seg av såvidt alvorlige problemer - for det er gjerne grov og gjentatt mishandling det er tale om - blir sentret ikke sjelden utfordret av politikere og myndigheter som påpeker mangel på profesjonelle folk i krisesentrets drift. Dette er, liksom det kjønnsspesifikke i tiltaket, et sentralt poeng. Det skal ikke være for profesjonelt drevet, det er viktig at det er vanlige kvinner som tar imot, at de som kommer møter kvinner i samme situasjon og at kvinnene selv er med å bestemme sentrets drift og rytme. Man ønsker nettopp ikke å profesjonaliseres, men er selvsagt behjelpelig med videre henvisninger til myndigheter og profesjonell hjelp. Kvinnene får ofte følge til legevakt, til offentlige kontorer for å ta opp sin sak, o. 1. I dette ligger for så vidt ingen underkjennelse av at andre ressurser enn sentrets også må til, bare en understreking av det viktige ved det alminnelige i opplegget.

\section{Hustruvoldens ulbredelse}

Finnes det andre data om hustruvoldens utbredelse enn dem man kan hente fra krisesentererfaringene? Opplysningene fra før 1970-tallet er spredte og indirekte. Man kan plukke sammen statistiske og andre data fra forskning som er blitt til ut fra et annet siktemål enn kartlegging av hustrumishandling. I første rekke vil det si å trekke på erfaringene fra den kriminologiske draps- og voldsforskning. Men som nevnt innledningsvis er hustruvolden lite synlig i dette bildet. Det er ikke ofte offersituasjonen er systematisk undersøkt, og når den undersøkes - gjerne i interaksjon med gjerningsmannen - så er forskningsresultatene ofte gjengitt i kjønnsnøytral form. Det snakkes om »familievold « og »ektefellevold« uten å differensiere etter kjønnsvariablen. Man burde heller bruke begreppet »hustruvold" som er 
langt mer adekvat ut fra kvantitative og kvalitative kjennetegn ved ektefellevolden. Alt dette betyr at man får lite ut av resultatene, og at tolkingen av dem ofte er usikker og at det er enda vanskeligere å trekke sammenlikninger mellom de ulike resultater her enn på andre områder. Jeg skal likevel søke å gi noen hovedinntak gjennom draps- og voldsforskningen. Skilsmisseforskning er også et inntak, men det lar jeg av arbeidsmessige grunner ligge i denne sammenheng.

Drapsforskningen gir de klareste utsagn om kjønnsretningen mellom gjerningsmann og offer, antakelig fordi drap er et alvorlig lovbrudd og fordi det er på det rene hvem som er det endelige offer. På den annen side er den kvantitative fordeling på kvinner og menn når det gjelder ektefelledrap en annen enn når det gjelder ektefellevold. Blant ektefelledrapene finnes en viss andel drapskvinner, mens ektefellevolden gjør voldsmenn til den helt dominerende kategori.

La meg først oppsummere funnene fra drapsforskningen i flere land gjennom hele hundreåret, for deretter å gi et par konkrete eksempler på slik forskning:

Menn begår langt flere drap enn kvinner. Drap av kjente ofre er langt vanligere enn av ukjente. Menn dreper oftest menn, men nesten like ofte kvinner når det er tale om tidligere kontakt mellom gjerningsmann og offer. Kvinnelige ofre er meget ofte gift med sin drapsmann eller har et seksuelt forhold til ham. Slik er det ikke med mannlige drapsofre. Hustruer som er myrdet lider vanligvis en sterkt voldelig død - de slås til døde. Den mannlige draps- og ektemann er ofte kjent av myndighetene for tidligere vold mot hustruen - det er ikke tilfelle for drapskvinner. Det mannlige drapsoffer er ikke sjelden kjent av myndighetene for tidligere voldsbruk. Dette gjelder ikke kvinnelige drapsofre.

At hjemmet er et farlig sted for voldelig død er erkjent og den kjønnsspesifikke retningen er klar: fra ektemann til hustru, fra elsker til elskerinne. Som von Hentig skriver: »Når en kvinne er drept, undersøk blant hendes slektninger, særlig hendes ektemann, deretter hendes elsker." Han viser at av alle kvinner drept i Tyskland i 1931 var $61 \%$ hustruer.

MacDonald uttaler at mord i England - og antakelig i alle land - betyr mord av menn. Han gjengir drapstall med dødsdom til følge fra en rekke land, men det er bare for England at han differensierer etter kjønn. Av 551 slike drap i tiden $1886-1905$ var det 487 med mannlig gjerningsmann. Nesten halvparten av mennene hadde drept sine hustruer og elskerinner (239). Han gir ingen tilsvarende opplysninger når det gjelder de 64 drapskvinnene. Undersøkelser av Gibson viser samme tendenser for etterkrigstidens England. Av 1413 dømte drapsmenn i tiden 1967-71 var det 1157 menn og 256 kvinner, mens kjønnsfordelingen på offersiden var en ganske annen, med omtrent like mange kvinner som menn blant ofre over 16 år (597 mot 592). Kvinnene ble i langt større grad enn mennene drept av sine 
egne, idet hustruer og elskerinner utgjorde $57,8 \%$ av kvinnelige of re, mens ektemenn og elskere utgjorde $13,3 \%$ av de mannlige.

Wolfgangs undersøkelse av 550 drap i Philadelphia i 1948-52 viser at $25 \%$ av drapene var familiedrap og at majoriteten var hustrudrap. Voss og Hepburns gjennomgåelse av 383 drap i Chicago i 1965 viser at $41 \%$ av alle kvinnelige ofre ble drept av ektemenn ${ }^{13}$ ).

Voldsforskningen understreker de samme tendenser, bare med en sterkere kjønnsretning, der opplysninger om kjønnsretning finnes. Som nevnt forbigås oftest kjønnsvariablen $\mathrm{i}$ voldsforskningens offerside, og når den berøres skjer det gjerne overfladisk, slik at tolkingen blir vanskelig. La meg illustrere dette med et eksempel:

McGlintock har i etterkrigstiden vært en av de europeiske forskere som sterkest har konsentrert seg om voldsforskning. Likevel gir han i sine mange arbeider fra 1960- og 70-årene få opplysninger om voldens retning. Selv når han - så sent som i 1978 - tar familievold spesielt opp i en artikkel, er han gjennom hele artikkelen sjenerende kjønnsnøytral. Dersom siktemålet er å framstille virkeligheten best mulig, må hans kategorier og diskusjon av egne resultater regnes som mindre hensiktsmessige ${ }^{14}$ ).

Kjønnsnøytralitet eller forbigåelse av temaet kjønn er forholdsvis alminnelig i den generelle voldsforskning. Jeg har selv erfart at det krever mye arbeid og gir lite utbytte å lete seg gjennom den for å få informasjon. Jeg nøyer meg derfor med denne ene referansen til tradisjonell forskning på feltet, for å gå over til den forskning som i 1970-årene har konsentrert seg om familievold, og ganske særlig hustruvold, i studiet av vold mellom voksne. Store deler av denne forskningen er mer eller mindre feministisk inspirert, enten det er kvinner eller menn som har gjennomført $\operatorname{den}^{15}$ ).

I USA har Straus, Gelles og Steinmetz foretatt flere undersøkelser. De understreker hvordan vold mellom familiemedlemmer er vanligere enn vold mellom noen andre i USA, når man ser bort fra krig og opprør. I flere arbeider tar de særlig opp hustruvold og framhever dens til dels normale, men også sammensatte og motstridende karakter. De bygger sine synspunkter på dybdeintervjuer med 40 ektepar hvor man visste det hadde forekommet vold, og 40 ektepar i nabolaget til disse hvor man ikke visste noe på forhånd, på gjennomgang av innholdet i ulike massemedia og på intervjuer med et representativt utvalg på 2146 familier $\left.^{16}\right)$.

13) Von Hentig 1948, MacDonald 1911, Gibson 1975 (og Gibson og Klein 1969 for de samme tendenser $i$ årene 1957-1968), Wolfgang 1958, Voss and Hepburn 1968.

14) McGlintock 1978.

15) Pethick 1979 gir en fyldig annotert bibliografi over 1970 årenes forskning $i$ USA og Storbritannia.

16) Gelles 1972 var den første boka som kom og den siste, som alle tre står som forfattere av, er under trykking. Pethick 1979 kommenterer flere av deres artikler og videre referanser finnes også i Gelles 1978. 
Forskningsmiljøer har også vokst direkte fram av krisehjelpsbevegelsen. Martins bok om hustrumishandling (1976) var den første større bok om emnet fra en av de aktive i krisesenterbevegelsen i USA ${ }^{17}$ ).

I Storbritannia er det særlig det skotske forskerparet Dobash og Dobash som bør framheves. Ett av deres grunnlag er gjennomgang av alle voldssaker ved visse skotske domstoler i 1974, 3000 saker. 29\% av disse dreiet seg om familievold. I familievoldssakene var $97,4 \%$ av gjerningsmennene menn, mens det var $95 \%$ kvinnelige of re. Ektemenn ble sjelden angrepet, bare i $1,1 \%$ av sakene, mens hustruofre utgjorde $75 \%$. I $92 \%$ av sakene var det mann mot kvinne: ektemann mot hustru, sønn mot mor, bror mot søster, far mot datter ${ }^{18}$ ).

Dobash og Dobash har også foretatt dybdeintervjuer med 109 mishandlede kvinner som har oppsøkt krisesentre og jeg vil komme tilbake til innholdet av disse $\mathrm{e}^{19}$ ).

Hjemmet er ikke farlig for menn fra et voldssynspunkt. Men hjemmet er farlig for kvinner, og særlig for kvinner som er hustruer.

I Norden finnes det flere undersøkelser som direkte tar for seg privatlivets ufred gjennom politiopplysninger om husbråk.

Den mest utsagnskraftige er Peltoniemi og Puustinen som undersøker "bostadsalarmer « til politiet i Helsingfors i 1977. Det var 8821 alarmer med konsentrasjoner mot ukeslutt, til visse strøk $\mathrm{i}$ byen og til bestemte adresser (politiet gjenkjente hver fjerde alarmadresse). 320 saker ble særlig undersøkt. I disse utgjorde familiekrangel $60 \%$. 50\% gjaldt krangel mellom ektefeller. Fysisk vold fant man mindre av enn man ventet, verbal vold, trusler og skadeverk var vanligere. I hver fjerde sak var det fysisk vold og i ca. halvparten av disse gjaldt saken hustruvold. Alkoholen blir trukket fram som en nesten unntaksfri regel i forbindelse med familievolden, idet $90 \%$ av gjerningsmennene i voldssakene og $58 \%$ av of rene var beruset. Prosentsatsene for hustruvoldssakene er ikke angitt ${ }^{20}$ ).

Dersom man kan tillate seg å generalisere opplysningene fra de $320 \mathrm{og}$ 8821 sakene, skulle det bety at Helsingforspolitiet tilkalles til ca. 4400 ektefellekrangler i året med trusler, skadeverk eller vold. I ca. 1000 av sakene skulle det dreie seg om fysisk hustrumishandling, og ettersom over 2000 av husbråkadressene var velkjente for politiet, må vi ut fra hva vi ellers vet regne med at endel av hustruvolden skjuler seg bak disse.

Vanskeligere ex det å trekke ut opplysninger fra Svensson og Danielsson som undersøker 460 saker om »lägenhetsbråk« i et politidistrikt i Stockholm

17) Martin 1976, se også Martin 1979.

18) Dobash and Dobash 1978.

19) Dobash et al. 1978. Oversikt over britisk forskning får man også i Martin, J. P., ed. 1978 og Renvoize 1979.

20) Peltoniemi og Puustinen 1979. 
i mai og november 1977. Blant disse var det 5-6\% dokumenterte voldssaker, men ved nærmere gransking av dagboksføringen framgikk det at volden hadde en langt større forekomst enn den som ble videre registrert. Etter løse anslag regner de med at ca. $70 \%$ av volden blir underrapportert og mener at de burde være tilstede ved utrykning for å få et rett bilde av situasjonen, så lenge registreringssystemet foregår som i dag. Ut fra det materiale de har, konkluderer de med at »når vold forekom i forbindelse med husbråk, er det ofte kvinnen som har blitt utsatt for volden $\ll^{21}$ ).

Fodstad og Steen forsøkte å få inntak til hustruvolden gjennom politiopplysninger, men også de fant det vanskelig ut fra de registreringsrutiner som ble fulgt. De påpeker hvordan kategorien husbråk er kjønnsnøytral og tildekkende. Både Fodstad og Steen, og Aslaksen og Nisja som nå er i gang med en intervjuundersøkelse blant politifolk ved flere stasjoner i Oslo, formidler at politiet opplever hustruvolden i husbråksakene som et hyppig, alvorlig og vanskelig problem som de føler seg temmelig maktesløse overfor $^{22}$ ).

Om vi går videre etter politidata om vold vil Melings hovedoppgave i kriminologi gi litt. Men ettersom hverken hustruvold eller familievold var hans siktemål, er det bare noen indirekte opplysninger vi kan trekke ut: Av ca. 2400 saker ved 9 politikamre i 1967 og 1969 var åstedet for forbrytelsen privat i $66 \%$, og det var langt flere kvinnelige ofre med privat åsted enn mannlige. Mer forteller det antakelig at i $23 \%$ av sakene var åstedet felles bolig mellom gjerningsmann og offer eller offerets bolig, og i $18 \%$ av sakene gjaldt volden vold mellom ektefeller, tidligere ektefeller, forloveder $\mathrm{m}$. v. Voldens retning i forhold til disse tallene tar Meling ikke opp ${ }^{23}$ ).

Det finnes også andre problemmottakere for hustruvold enn politiet. Leger, sykehus, legevakt, sosialkontorer, advokater, skilsmissemyndigheter har erfaringer. Noen slike erfaringer er forsøkt systematisert i den internasjonale litteraturen, men i Norden har vi, såvidt jeg vet, lite.

Bergersen Linds undersøkelse av voldsofre innbrakt til Ullevål sykehus i 1967 understreker de internasjonale mønstre, men hennes tall er små: hun finner at det dreier seg hovedsakelig om vold mellom kjente, særlig vold mellom ressurssvake og alkoholpåvirkede menn. $16 \%$ av voldsofrene var kvinner og de fleste var slått ned hjemme av berusede eller ikke-berusede ektemenn. Ofrene var oftest $\mathrm{i}$ edru tilstand i motsetning til de mannlige of $\left.\mathrm{re}^{24}\right)$.

Som ledd i det nordiske kriminalitetsskadeprosjektet under Nordisk samarbeidsråd for kriminologi ble det foretatt liknende legevakt- og sykehus-

21) Svensson og Danielsson 1978.

${ }^{22}$ ) Fodstad og Steen 1977.

23) Meling 1975 .

24) Lind 1969. 
undersøkelser i de øvrige nordiske land. Men de forteller mindre enn Bergersen Linds både fordi tallene er små, og fordi undersøkelsene hadde andre siktemål enn vold mot kvinner og fordi det ikke er lagt vekt på hjemmet som åsted. Skulle man likevel trekke noe ut, er det at kvinner i mindre grad enn menn utsettes for vold og at volden mot kvinner later til å ha en mindre alvorlig karakter enn vold mot menn. Begge utsagn trenger nærmere presiseringer i datagrunnlag og tolking ${ }^{25}$ ).

Også andre sider ved det nordiske kriminalitetsskadeprosjektet kunne hatt muligheter i seg fra kvinnesynspunkt dersom undersøkelsene hadde vært noe annerledes lagt opp. Jeg tenker på offerintervju-undersøkelsene for kartlegging av de faktiske ofre for hverdagsvold.

Wolfs sammenliknende rapport på grunnlag av det finske og danske gallup-materialet har hele tiden kjønnsvariablen med $\mathrm{i}$ bearbeidning og tolking, men blir likevel ikke viktig i denne sammenheng, fordi spørsmålsstillingen og intervjusituasjonen er slik at man må anta at lite av privatvolden oppfanges og fordi kjønnsvariablen ikke utnyttes tilstrekkelig i tolkingen på det punkt hvor tolking ville være interessant: hjemmet som åsted (ca. $12 \%$ av de danske voldshandlinger). Generelt avdekker undersøkelsen at kvinner utsettes for mindre vold enn menn, men ikke mye mindre, at hverdagsvolden ikke har noen særlig alvorlig karakter, at vold mot kvinner er mindre alvorlig enn vold mot menn, men at det også her er mindre kjønnsforskjeller enn ventet. Wolf uttaler at resultatene kan være vanskelige å tolke fordi forholdet antakelig er det »at det virkelig er forskjell på den mengde og de former for vold som menn og kvinner utsettes for, at det likeledes er forskjeller i deres oppfatning av hva vold eller trussel om vold egentlig er, men at vi ikke for tiden kan si noe videre om hva disse forhold innebærer for det kriminalpolitiske arbeid eller for kriminologisk teori«. Ut fra det som er sagt ovenfor må han ha rett $\mathrm{i}$ dette, samtidig som vi i dag vet mer om forholdet mellom vold mot kvinner og menn. Hauge tar et uttrykkelig forbehold når det gjelder gallup-tallenes evne til å fange opp vold mot kvinner i hjemmet ${ }^{26}$ ).

\section{Hustruvoldens dynamikk og kjennetegn}

Den kriminologiske volds- og drapsforskning gir liten eller ingen veiledning m. h. t. hustruvoldens nærmere innhold. Man må gå til de erfaringer som ligger i direkte kontakt med mishandlede kvinner gjennom intervjuundersøkelser, krisesentre, rettshjelpstiltak og andre hjelpetiltak. Jeg vil trekke fram to intervjuundersøkelser, en skotsk og en amerikansk, og gi noen norske erfaringer fra JURK og krisesentret.

26) Wolf 1972, Hauge 1972. 
Det skotske forskerteamet under ledelse av Dobash og Dobash har foretatt dybdeintervjuer med 109 mishandlede kvinner som har oppsøkt Women's Aid som administrerer krisesentrene i Skottland. Ofrene ble spurt om den første voldsepisoden de opplevde, den verste og den siste. Dessuten ble det innhentet informasjon om parforholdets og ekteskapets utvikling og om hustruens og ektemannens bakgrunn.

Før ekteskapsinngåelse hadde de fleste av kvinnene opplevd ulike faser i sitt parforhold, fra det å gå sporadisk ut sammen, mot en nærmere tilknytning mellom partene med mer alvor - en tilknytning som samtidig innebar en begrensning av omgang med venner av samme kjønn - særlig for kvinnenes del, hvor $61 \%$ så å si helt sluttet å være sammen med sine venninner på egenhånd, mot $41 \%$ av mennene. Kvinnene opplevde $\mathrm{i}$ denne fasen stor oppmerksomhet fra mannen og det var en tilfredsstillende periode. Denne gled over i økende eksklusivitet, eiendomsfølelse og eiendomsbesittelse særlig fra mannens side. Mange av kvinnene tok dette som et tegn på hans sterke engasjement, andre følte allerede da et varsel om sterkere kontroll fra mannens side enn de selv ønsket. Noen menn slo før ekteskapsinngåelse - $23 \%$ - og det var stort sett i forbindelse med sjalusireaksjoner eller ved utsikten til at kvinnen skulle tenke på å avslutte forholdet.

Det var altså etter ekteskapsinngåelsen at kvinnene ble utsatt for vold $59 \%$ i løpet av det første året, $92 \%$ i løpet av de første 5 årene, og de fleste opplevde gjennom ekteskapet en ytterligere isolering fra omverdenen og tidligere bekjentskapskrets.

Første gang var vanligvis ikke så alvorlig ut fra et skaderesultatsynspunkt, men ikke sjelden ble det en sjokkartet opplevelse. Kvinnens reaksjon var å se det som en enkelt episode, og den ble ofte unnskyldt fra mannens side, og også fra hennes.

Det var vanskelig for mange av kvinnene å velge ut den verste episoden, fordi det ofte var spørsmål om å velge én blant like. Det var vanlig å legge vekt på skadens fysiske omfang, men også på om volden hadde en særlig ydmykende karakter - som f. eks. at offeret ble pisset på etterpå - eller at den hadde særlig ødeleggende sidevirkning som f. eks. oppløsning av et barns fødselsdag, ødeleggelse av julaften eller materiell ødeleggelse av møbler og annet inventar.

Siste angrep var gjerne det som hadde ført til kontakt med krisesentret. Det var ofte av alvorlig karakter, men ikke vesentlig annerledes enn tidligere angrep - i hvert fall ikke i fysiske kjennetegn. Det dreide seg oftere om et psykisk skifte ved at kvinnen var kommet $\mathrm{i}$ en slik situasjon at hun prøvde å gjøre noe med sin situasjon, flykte eller bygge seg opp selv og på nytt, ikke sjelden fordi barna var blitt så gamle at kvinnen mente de kunne klare seg selv.

De fysiske skadene kunne være ganske omfattende - hodeskader, indre lesjoner, benbrudd på forskjellige deler av kroppen, selvfølgelig hevelser, 
blåveis og blåmerker, kutt etc. Undersøkelser av krisesentersøkende kvinners fysiske skader er spesielt foretatt ved London-sentret og det viser seg at varige mén heller ikke er en sjeldenhet. Kvinnene hadde tidligere ofte vært behandlet hos lege, på legevakt og på sykehus, men overraskende ofte vært hjemme for å leges, med skam- og skyldfølelse forbundet med å vise seg ute. Overhodet later skam- og skyldfølelse til å være viktige faktorer bak privatiseringen av volden også fra kvinnens side. Politi blandes bare inn når nødvendig eller er blitt tilkalt av naboen, og bare 2 av de 109 kvinnene hadde inngitt anmeldelse.

Volden blir svært ofte utløst av bagateller - slik kvinnene oppfatter det episoder som faller i tre mønstre: sjalusi -. of te ubegrunnet ifølge kvinnene - ikke tilfredsstillende oppfyllelse av huslige plikter, og diskusjoner om familiefinanser.

Totalbildet var g.jentakende og vedvarende vold over lang tid, og kvinner gjennomsyret av stadig angst for nye angrep ${ }^{27}$ ).

Walker har gjort dybdeintervjuer med 120 mishandlede kvinner som hun har fått kontakt med gjennom sin psykoterapeutiske praksis og på annen måte. Dessuten har hun foretatt ytterligere 300 kortere intervjuer med endel mishandlede kvinner og deres hjelpere. Hun understreker de dynamiske sidene ved offerprosessen, både når det gjelder de konkrete voldshandlingene og gjennom kvinnenes livsløp. M. h. t. den konkrete volden framsetter hun en syklusteori om voldens tre faser: oppbyggingsfasen, eksplosjonsfasen og kjærlighetsfasen. Ut fra dette fremmer hun forslag om forebygging. Når mange kvinner ikke forlater et voldspreget forhold, mener Walker at det henger sammen med økonomisk og annen avhengighet, hensynet til barna, terror, frykt og ikke noe sted å gå til $\left.{ }^{28}\right)$.

Mye av mishandlingsforskningen bekrefter disse kjennetegn av avhengighet, angst, isolasjon og mangel på muligheter. Det gjør også de norske erfaringene fra JURK og krisesentret.

Vi har registrert de første 656 innkomne sakene i form av brevhenvendelser til JURK på en full-tekst database, og jeg har gjort en rask, men av tidsnød overflatisk, gjennomgang av disse. Med utgangspunkt i ordene »vold «, »mishandling«, »brutal«, »slå «, »slag «, »spark« var det 130 brev som skilte seg ut ved ordsøkingen.

Ved nærmere gjennomlesing var det i flere av disse ikke kvinnene selv som ble utsatt for vold eller volden var ikke en særlig viktig side ved brevet. I over 50 av sakene var vold imidlertid et problem som det var verdt å merke seg.

Volden later til å være en integrert del av mange forholdsvis uutholdelige samliv. Den er vanligvis ikke årsaken til at kvinner henvender seg til

27) Dobash et al. 1978 .

28) Walker 1979. 
JURK. Årsaken ser oftest ut til å være at de søker seg ut av forholdet og vil ha orientering om sine rettigheter $\mathrm{m}$. h. t. felles bolig og eventuelle barn. Men i mange - overraskende mange - av sakene er kvinnene ganske godt opp i årene og henvender seg fordi de mener tiden da er inne til å bryte ut etter både 20 og 30 års ekteskap fordi barna er blitt voksne og kan klare seg selv. Det er således et gjennomgående trekk at det er hensyn til barn som gjør at mange av kvinnene holder ut så lenge, og bare blander lege og politi inn når det har vært helt nødvendig.

Også i JURK-sakene skriver noen av kvinnene om skadenes omfang, men ofte om dens sidevirkninger og ydmykende karakter - at middagsmaten blir klint i ansiktet på dem, at de blir sparket liggende på gulvet, samtidig som de får høre at de ikke er mer verdt enn en dørmatte. Det hender også at de materielle skader blir beskrevet - det er gjerne i forbindelse med alkohol at disse inntrer: slår inn inngangsdøren til tidligere ektefelle, knuser vinduer, senger, andre møbler, glass og tallerkener. Men det er påfallende hvor liten rolle alkohol later til å spille. Selvsagt er de sakene hvor alkohol er innblandet ofte de vanskeligste og de tøffeste. Men den ikke-berusede voldelige ektemann er et like vanlig, om ikke vanligere, trekk enn de berusede. Over halvparten av kvinnene på krisesentret i Oslo oppgir upåvirket gjerningsmann. Det samme forteller data fra Skottland, England og USA (den refererte finske undersøkelsen gir et annet inntrykk).

De inntrykk jeg har fått gjennom lesningen av JURK-sakene er ytterligere blitt bekreftet gjennom samtaler med JURK's og krisesentrets daglige ledere. Det er ikke voldens avvikende trekk som er mest påfallende, men dens funksjon som integrert del av hverdagslivet i disse ekteskapene.

\section{Slutlord}

Hvor omfattende er hustruvolden totalt sett? Det vites ikke. Men hustruvoldens andel av den registrerte kriminalitet kan tyde på at vold i ekteskapet ikke er uvanlig, og da i retning fra mannen mot kvinnen.

Erfaringene fra krisesentrenes virksomhet forsterker bildet. Den faktiske forekomst av familievold viser seg å være langt mer omfattende enn den registrerte, og det at det er kvinnene som særlig utsettes for den, reiser behov for spesielle tiltak. Det er bare et fătall av mishandlete kvinner som går til politianmeldelse. Dessuten er det et særlig håndhevingsproblem i disse sakene at ofrene så ofte trekker sin anmeldelse tilbake. Strafferettslig intervensjon blir både sjelden og vanskelig. Også annen myndighetsintervensjon i form av støtte til ofrene har vist seg vanskelig, mens privatiseringen av problemet bidrar til å holde det skjult.

Hvorfor oppstår volden og hvorfor er den såvidt utbredt?

Eldre teorier om personlighetsavvik og sykdom er utilstrekkelige her. Ingen vil benekte at det $\mathrm{i}$ visse forhold finnes patologiske og sterkt avvikende gjerningsmenn, særlig i parforhold hvor overdreven alkoholbruk 
er med i bildet, eller i de som beherskes av sykelig sjalusi. Men slike ekstreme forhold forklarer ikke utbredelsen. Forskningen fra de siste årene viser overhodet at det er vanskelig å »utpeke« voldelige ektemenn. De finnes i alle sosiale lag og ser ikke ut til å ha særlige felles kjennetegn, bortsett fra ett: Flere undersøkelser tyder på at mennene selv har opplevd familievold i sin barndom uten at dette i samme grad synes å gjelde for deres ofre.

Vi må altså søke mot mer strukturelle voldsteorier som bidrar til et normalitetsperspektiv på fenomenet.

Det er nærliggende å ty til Christies modell for det tette, voldsskapende samfunn: „Der hvor menneskene er bundet sammen, ser og opplever hverandre som helheter, liker eller misliker, elsker eller hater, men samtidig hele tiden er knyttet tett, tett sammen i varige bånd. Konflikter blir her slike man enten må leve med, eller løse. De kan ikke bare forlates. Det er ingen annen virkelighet, ingen annen arena. Det blir livs- eller dødsviktig her og nå.« Christie nevner »ektefellene som koker over« som eksempel på den tette vold ${ }^{29}$ ).

Det er klart at familieinstitusjonen har slike sosiologiske kjennetegn og at tett samliv skaper slitasje og aggresjon. Men dette forklarer ikke voldens kjønnsretning, med mindre man mener at fordelingen av fysisk styrke er den overveiende årsak. Modellen kan heller ikke uten videre forklare hvorfor kvinnene forblir i ekteskapet, når skilsmisseadgangen er så åpen som $\mathrm{i}$ Norge, eller hvorfor hustruvolden er såvidt akseptert uten myndighetsintervensjon.

Også den marxistiske modelltenkning om familien har begrenset bærekraft. Klart nok er det slik at det ytre samfunns problemskapende faktorer speiles i familien, og her vil noen familier være mer utsatte enn andre. Ulike typer av fattigdom og svak posisjon i lønnsarbeidet gir stress i privatlivet som kan medvirke til utløsning av voldssituasjoner. Den alminnelige privatisering av familien som følge av vår samfunnsform forsterker stresset ved å skjerme mot myndighetsintervensjon. Brückner gir gode inntak til å forstå viktige sider ved barnemishandling og familiens situasjon $\left.{ }^{30}\right)$. Hans resonnement gjelder også viktige sider ved hustrumishandlingen. Det er belegg for å si at hustrumishandlingen har en klassedimensjon i den forstand at noen hustruer blir særlig hardt rammet ved å fanges inn $i$ en vedvarende vanskelig og voldelig hverdag der utgangene blir få fordi økonomi og andre ressurser mangler. Mye av forklaringen på at en del kvinner blir i ekteskapet på tross av volden, ligger i de materielle barrierer mot å bryte ut ved skilsmisse eller på annen måte.

Et alminnelig grunnlag for gjentatt vold synes således å ligge både i familiens tette organisasjon, og i samfunnets økonomiske ordning. Men

29) Christie 1975:54.

30) Brückner 1974. 
fortsatt står store deler av voldsbildet uforklart. For å komme nærmere, må vi antakelig trenge inn bak familien som institusjon og se på forholdet mellom de enkelte familiemedlemmer.

Familie- og ekteskapsforskningen har tradisjonelt hatt en tendens til å se familien som en enhet hvor de enkelte medlemmene utfyller hverandre $\mathrm{i}$ mer eller mindre harmoni så lenge ekteskapet består. Når problemene blir synlige og skilsmisse kommer på tale, har det ofte ligget under at det dreier seg om et oppgjør mellom voksne og likestilte mennesker.

Nyere forskning dokumenterer stadig bedre at det egentlig er to typer ekteskap som må studeres. Det er »hans ekteskap« og det er »hennes«, og innholdet og hverdagslivet bak kontraktene mellom de to er vesensforskjellige. Ikke bare er oppgaver og arbeid ulikt fordelt, det er også tale om en ujevn maktfordeling der hun trekker det korteste strå på de fleste felter.

Det er ikke mer enn hundre år siden hans ekteskap helt overskygget hennes, at han hadde rettslig handleevne på hennes vegne, at hun ikke kunne disponere over de pengene hun hadde tjent, at han hadde rett til fysisk refselse, o.s. v. Mye er forandret siden, men ikke så mye som den formelle likestillingen gir uttrykk for og nettopp her, i mannens kulturelle maktposisjon, ligger kanskje en tilleggsforklaring på den utstrakte hustruvold.

Jeg har i en annen sammenheng sammenliknet ekteskapskontrakten med tidligere tiders husmannskontrakt og hevdet at husmoren er vår tids husmann. For mange kvinner betyr ekteskapet et liv i økonomisk, psykisk og fysisk avhengighet av mannen, med små bevegelsesmuligheter, på samme tid isolert og kontrollert. Fysisk vold er det ytterste kontrollmiddel, som endel ektemenn benytter seg av, når hustruen ikke oppfyller sine hustruplikter eller ikke oppfører seg som han ønsker eller forventer ${ }^{31}$ ).

Volden er et utslag av den rett til hustukt som de kulturelle normer har tillagt mannen, ikke vesensforskjellig, bare gradsforskjellig fra hva som er tillatt og akseptert i ekteskapelig samhandling. Denne hustuktteori til forklaring av hustrumishandling befestes i flere av de undersøkelser jeg har redegjort for.

Det later til å være slik at enhver kvinne kan komme opp i et voldelig samlivsforhold, og risikoen for dette er antakelig størst dersom ektemannen selv har opplevet vold i familien.

Det later også til å være slik at hustuktens berettigelse oppleves ulikt av ulike kvinner. På offersiden viser undersøkelser at det er gradvise overganger fra akseptasjon til klar avvisning, og her gir hustuktteorien et bidrag

31) Dahl 1976. Kinberg m. fl. 1943 gir eksempel på andre utslag av husfarens maktposisjon - hans adgang til ulovlig tilfredsstillelse av seksuelle behov overfor døtre. Forfatterne viser hvordan døtre i isolerte familier, svenske gårdsarbeidere, er særlig utsatt for incest. 
til å forklare hvorfor mange kvinner finner seg i mishandling og forblir i sine ekteskap. For norske forhold viser f. eks. Osmundsens ekteskapsundersøkelse at kvinners holdning til ekteskapet før de gifter seg er med å bestemme hvor mye de finner seg i mens ekteskapet består og hvor lenge de holder ut, dersom vold oppstår og gjentar seg. Kvinner som hadde det Osmundsen beskriver som et tradisjonelt syn på ekteskapet fant seg i mer før de skilte seg enn de som hadde likestilling mellom kvinne og mann som utgangspunkt..32)

Det syn man har på ekteskapet vil ha betydning for den videre utforming av hustuktteorien. Dersom man mener mannens overlegenhet er legitim - selv om fysisk vold er å gå for langt - vil hustrumishandling lett kunne nøytraliseres gjennom synspunkter om provokasjon. Det samme vil være tilfelle om man tror på forestillingen om gjennomgående like parter i ekteskapet. Selv mener jeg at vedvarende vold i et forhold må ses som uttrykk for ektemannens ønske om å etablere og opprettholde makt over sin hustru.

Tove Stang Dahl

\section{LITTERA'TURLISTE}

Alfredsson, Karin 1979: Den man älskar agar man? Rabén \& Sjögren.

Amir. Menachem 1971: Patterns in Forcible Rape. The University of Chicago Press.

Brownmiller, Susan 1975: Against Our Will: Men, Women and Rape. Secker \& Warburg, London.

Brückner, Peter 1974: Kapitalismens socialpsykologi. Hans Reizel.

Christie, Nils 1975: Hvor tett et samfunn. Christian Ejlers' Forlag, Universitetsforlaget.

Dahl, Tove Stang m. fl. 1975: Juss og juks. En arbeidsbok i likestillnng. Pax Forlag.

Dahl, Tove Stang 1976: „Ekteskapet — den moderne husmannskontrakten. Noen kvinnerettslige problemstillinger.« Støren og Wellesen red. 1976.

Dobash, R. Emerson and Russell P. Dobash 1978: Wives: The 'Appropriate' Victims of Marital Violence. Victimology: An International Journal, Vol. 2, $3-4$, s. $426 \mathrm{ff}$.

Dobash, R. Emerson et al. 1978: »Victimology Interview: Wife Beating: The Victims speak«. Victimology: An Inlernational Journal, Vol. 2, 1977-78, 3-4, s. $608 \mathrm{ff}$.

Fodstad, Hjørdis og Karen Sofie Steen 1977: „Det skjulte martyrium. Omkring synliggjøring av brutalitet mot kvinner i hjemmet.« Institutt for kriminologi og strafferett, Univ. i Oslo, stensilserie nr. 26.

Gelles, Richard J. 1972: The Violent Home: a Study of Physical Aggression between Husbands and Wives. Sage Publications.

32) Osmundsen 1979. 
Gelles, Richard J. 1978: »Violence in the American Family«. Martin, J.P. ed. 1978.

Gibson, Evelyn and S. Klein 1969: Murder 1957 to 1968. A Home Office Report on Murder in Englund and Wales. Her Majesty's Stationary Office.

Gibson, Evelyn 1975: Homicide in England and Wales 1967-1971. Her Majesty's Stationary Office.

Goldschmidt, Verner 1978: „Repression eller tolerance i retshåndhævelsen.« Festskrift till Per Stjernquist. Juridiska Föreningen i Lund, nr. 24.

Gummedal, Jan 1975: Voldskriminalitet blandt kvinner. Mellomfagsoppgave. Institutt for kriminologi og strafferett, Univ. i Oslo.

Hauge, Ragnar 1972: "Hverdagsvold i Norge.« Lov og rett, nr. 6, s. 259 ff.

Kempe, C. H. et al. 1962: »The Battered Child Syndrome. "Journal of Medical Associalion, 181, 17-24.

Kinberg, Olof m. fl. 1943: Incestproblemet $i$ Sverige. Natur och Kultur, Stockholm.

Koch, Nynne red. 1980 (under trykking): Kvindestudier 4, Delta Forlag.

Lenke, Leif 1973: "Den dolda våldsbrottsligheten i Stockholm — en sjukhussurvey.« $N T f K, 61$. årg., 2, s. $136 \mathrm{ff}$.

Lind, Brit Bergersen 1969: »Skadede ofre for vold i Oslo«. NTfK, 57. årg., 3-4, $207 \mathrm{ff}$.

Lykkjen, Asta Magni 1976: Voldtekt. Ei bok om kvinneundertrykking. Pax Forlag. MacDonald, Arthur 1911: "Death Penalty and Homicide." American Journal of Sociology, Vol. 16, s. $88 \mathrm{ff}$.

Martin, Del 1976: Baltered Wives. Glide Publications.

Martin, Del 1979: »What Keeps a Woman Captive in a Violent Relationship? The Social Meaning of Battering. « Moore ed. 1979.

Martin, J. P. ed. 1978: Violence and the Family. John Wiley \& Sons, Ltd.

McClintock, F. H. 1978: »Criminological Aspects of Family Violence.« Martin, J. P. ed. 1978.

Meling, Lars 1975: "Eg? - det var han som byrja." En sosiogeografisk studie av registrert voldskriminalitet $i$ Norge 1967-69. Hovedfagsavhandling, Institutt for kriminologi og strafferett, Univ. i Oslo.

Melville, Joy 1978: »Women in Refuges.« Martin, J. P. ed. 1978, s. $293 \mathrm{ff}$.

Moore, Donna M. ed. 1979: Battered Women. Sage Publications, Inc.

Osmundsen, Kari Moxnes 1979: Ekteskapet. Om ekteskapsproblemer og skilsmisseärsaker. Magistergradsavhandling i sosiologi, Univ. i Trondheim.

Peltoniemi, 'Teuvo og Meeri Puustinen 1979: »Familjevåld.« Alkoholpolitik, Vol. 42, s. $57 \mathrm{ff}$.

Pethick, Jane 1979: Battered Wives: A Select Bibliography. Centre of Criminology, Univ. of Toronto.

Pizzey, Erin 1974: Scream quietly or the Neighbours will hear. Penguin Books Ltd.

Rasmussen, Ncll og Annalise Kongstad 1980 (under trykking): »Kilder til forståelse af voldtægt og brugen af dem.« Koch red. 1980.

Renvoize, Jean 1979: Web of Violence. A Study of Family Violence. Penguin Books Ltd.

Russel, Diana E. H. 1975: The Politics of Rape. The Victim's Perspective. Stein \& Day, New York. 
Russel, Diana E. H. and Nicole Van de Ven ed. 1976: Crimes against Women: Proceedings of the International Tribunal. Les Femmes, Millbrae, California.

Støren, Tordis og 'Tone Schou Wetlesen 1976: Kvinnekunnskap. Gyldendal.

Svensson, Bengt og Nils-Gunnar Danielsson 1978: Lägenhetsbråk. Kriminalvetenskapliga Institutet, Stockholms Universitet, stensil.

Von Hentig, Hans 1948: The Criminal and his Victim. Yale University Press.

Voss, Harwin L. and John R. Hepburn 1968: "Patterns in Criminal Homicide in Chicago." Journal of Criminal Law, Criminology and Police Science, Vol. 59,4 , s. $499 \mathrm{ff}$.

Walker, Leonore E. 1977: "How Battering Happens and How to Stop it.« Moore ed. 1979.

Weis, Kurt and Sandra J. Borges 1973: »Victimology and Rape. The Case of the Legitimate Victim." Issues in Criminology, Vol. 8, No. 2.

Westh, Anne-Birgitte 1974: "Skadebehandlede ofre for vold.« NTfK, 62. årg., 1, s. $64 \mathrm{ff}$.

Wolf, Preben 1972: Vold i Danmark og Finland 1970/71. En sammenligning af voldsofre. Forskningsrapport til Nordisk Samarbeidsråd for Kriminologi.

Wolfgang, Marvin 1958: Patterns in Criminal Homicide. University of Pennsylvania Press.

Årsrapport for Krisesentret for mishandla og voldtatte kvinner 1978, Oslo. 